\title{
ASPECTE CLINICE ŞI TERAPEUTICE ÎN COARCTAȚIA DE AORTĂ SEVERĂ CU CIRCULAȚIE SISTEMICĂ DUCTAL DEPENDENTĂ LA NOU-NĂSCUT
}

\author{
Alina-Costina Luca ${ }^{1,2}$, Andreea-Simona Holoc ${ }^{2}$, Constantin Iordache ${ }^{2}$ \\ ${ }^{I}$ Secția Clinică de Cardiologie Pediatrică, \\ Spitalul Clinic de Urgențe pentru Copii ,Sf. Maria “, Iaşi \\ ${ }^{2}$ Universitatea de Medicină şi Farmacie ,, Gr. T. Popa“, Iaşi
}

\begin{abstract}
REZUMAT
Coarctația de aortă are incidență de 0,6-0,8/1.000 nou-născuți, manifestându-se clinic din perioada neonatală. La nou-născut, malformațiile congenitale cardiace asociate cu insuficiență cardiacă şi răsunet clinic încă din primele ore de viață au un prognostic rezervat, necesitând un diagnostic precoce şi o conduită terapeutică adecvată. Prezentăm un caz clinic de coarctație de aortă severă cu circulație sistemică ductal dependentă, diagnosticat din perioada neonatală. Tratamentul precoce cu prostaglandină E1 a permis menținerea echilibrului hemodinamic, copilul beneficiind de corecție chirurgicală în prima lună de viață.
\end{abstract}

Cuvinte cheie: nou-născut, coarctație de aortă severă ductal dependentă, insuficiență cardiacă, prostaglandină E1, tratament chirurgical

Coarctația de aortă la copil reprezintă aproximativ $6-8 \%$ din totalul malformațiilor congenitale de cord, fiind a patra cea mai frecventă leziune care necesită intervenție chirurgicală sau cateterism în timpul copilăriei (1). Cele mai frecvente defecte asociate coarctației de aortă sunt persistența de canal arterial, DSV şi stenoza aortică. Astfel, bicuspidia aortică poate fi observată la aproape două treimi dintre copiii cu coarctație de aortă (2). Conform studiilor lui Abbott, pacienții supraviețuiesc, în medie, până la 33,5 ani (3). Dacă intervenția chirurgicală se efectuează precoce (până la 14 ani), supraviețuirea până la 20 ani după intervenție este de $91 \%$, iar în cazul corecţiei anomaliei tardive, supraviețuirea scade la $79 \%(4,5)$. Opțiunile de tratament includ intervenții chirurgicale, angioplastie cu balon şi stenting endovascular.

\section{PREZENTAREA CAZULUI}

Pacient A.D., în vârstă de 10 zile, se internează prin transfer clinic pentru cianoză generalizată, tahipnee, dispnee la efortul de supt şi investigarea unui suflu sistolic decelat în maternitate. Nou-născutul este primul copil al unui cuplu aparent sănătos (mama - 18 ani, tata - 22 de ani), născut natural, la o vârsta gestațională de 40 de săptămâni, având greutatea la naştere de $2.700 \mathrm{~g}$ şi APGAR: 8 la 1 minut şi 9 la 5 minute. La internare, copilul prezintă stare generală gravă, talia - 1,52DS, greutatea $-2,2 \mathrm{DS}$, perimetrul cranian $-2,9 \mathrm{DS}$, tegumente palide, elastice, hipotonie generalizată, cianoză perioronazală şi a extremităților, sindrom funcțional respirator sever: tahipnee, tiraj intercostal şi subcostal, FR: 35 respirații/minut, zgomote cardiace ritmice, tahicardice, cu frecvență cardiacă: 140 de bătăi pe minut, suflu sistolic grad IV/6 spațiul III i.c drept şi parasternal stâng, $\mathrm{SaO}_{2}: 65-70 \%$, puls femural nepalpabil bilateral, extremități inferioare reci, tensiunea arterială la nivelul membrului superior drept: 70/50 $\mathrm{mmHg}$, tensiunea arterială la nivelul membrului inferior drept: $50 / 30 \mathrm{mmHg}$, abdomen depresibil, ficat la $3,5 \mathrm{~cm}$ sub rebordul costal, tranzit intestinal şi micțiuni fiziologice, alimentat prin gavaj, FA:2/2 cm normotensivă. 
Paraclinic s-a remarcat o anemie carenţială şi trombocitoză.

Radiografia toracică relevă cord de dimensiuni crescute prin bombarea arcului inferior stâng, indice cardio-toracic de 0,61, vârful cordului ascensionat, circulație pulmonară încărcată.

Electrocardiograma relevă ritm sinusal 160/min, axa electrică la dreapta fiziologică $(+120$ grade), unde $\mathrm{T}$ aplatizate în derivațiile frontale, QT:0,28 sec uşor alungit.

Ecocardiografia 2D, secțiunea parasternal ax scurt, evidențiază hipertrofie concentrică a pereților ventriculilor şi aorta care prezintă 2 cuspe; secțiunea suprasternală, ax lung, permite aprecierea arcului aortic, zona de coarctație, dilatarea poststenotică. Prin suprapunerea Doppler color la nivelul coarctației şi în trunchiul arterei pulmonare se evidențiază un flux turbulent, iar prin suprapunerea Doppler continuu se înregistrează anvelopă cu velocitate crescută în sistolă.

S-a instituit tratament cu prostaglandina E1 în vederea menținerii permeabilității canalului arterial şi diuretic pentru terapia insuficienței cardiace.

Având în vedere starea clinică critică a pacientului la internare, evoluția lent favorabilă sub medicația instituită şi aspectul ecocardiografic, după
20 de zile de spitalizare se realizează transferul într-un centru specializat de chirurgie cardio-vasculară pediatrică unde se practică corecție chirurgicală.

După inducerea anesteziei, au fost realizate două linii arteriale: una la nivelul arterei radiale drepte şi alta la nivelul arterei femurale stângi pentru a măsura tensiunea arterială la nivelul membrelor superioare şi inferioare. Tensiunea arterială sistolică la nivelul radialei a fost cu $55 \mathrm{mmHg}$ mai mare decât tensiunea arterală sistolică la nivelul femuralei. După o toracotomie posterolaterală stângă la nivelul spațiului III i.c. s-a efectuat rezecția segmentului care cuprinde coarctația de aortă, urmată de anostomoza termino-terminală şi ligaturarea canalului arterial. Evoluția postoperatorie a fost favorabilă, dar cu adaptare hemodinamică dificilă, necesitând suport inotropic prelungit şi tratament vasodilatator în doze crescute pentru controlul valorilor tensionale. Întrucât postoperator s-a decelat prezența sindromului anemic ( $\mathrm{Hb} 8,8 \mathrm{~g} / \mathrm{dl}$ ), pacientul a necesitat administrarea de masă eritrocitară, fără a întâmpina reacții adverse.

Ecocardiografia a demonstrat flux normal în aorta descendentă, fără a exista gradient la nivelul anastomozei. Gradientul arterei pulmonare a fost

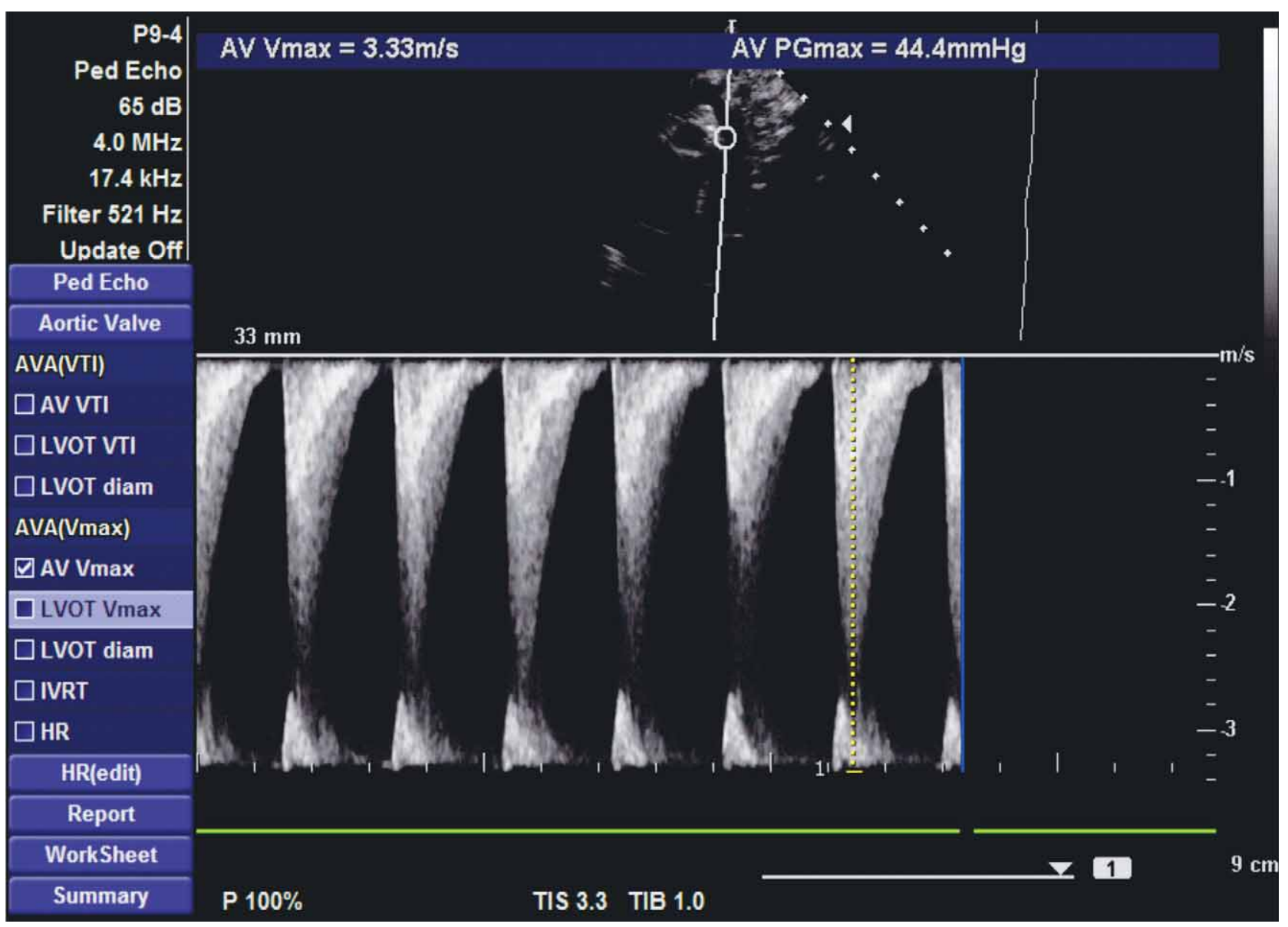

FIGURA 1. Pacient A.D. - Ecocardiografie transtoracică, secțiune suprasternală 
50 mm Hg (hipertensiune arterială pulmonară reziduală) fiind considerată satisfăcătoare.

La 8 luni postoperator, pacientul prezintă stare generală bună, tegumente normal colorate, cicatrice postoperatorie de aspect normal, suflu sistolic grad II/6 în spațiul II i.c. drept, AV:120 bpm, puls arterial bilateral la nivelul extremităților, TA la nivelul membrelor superioare: $102 / 61 \mathrm{mmHg}$, la nivelul membrelor inferioare: $110 / 65 \mathrm{mmHg}$, ficat la rebord. Ecocardiograma evidențiază prezența insuficienței cardiace congestive şi bicuspidie aortică.

Primeşte tratament cu captopril ( $3 \mathrm{mg} / \mathrm{zi})$, furosemid (1 mg/zi), spironolactonă (3,125 mg/zi), aspacardin, aspenter, profilaxia endocarditei infecțioase şi va fi evaluat periodic pentru monitorizarea tensiunii arteriale, urmărirea ecocardiografică a anomaliilor asociate şi eventualei restenozări.

\section{DISCUȚII}

Coarctația de aortă istmică reprezintă îngustarea aortei la nivelul joncțiunii dintre arcul aortic distal şi aorta descendentă, imediat sub originea arterei subclavii stângi. Prezența coarctației determină creşterea presiunii la nivelul aortei proximale şi a postsarcinii ventriculului stâng, iar la nivel distal presiunea este redusă. Când coarctația este asociată cu persistența de canal arterial are loc reîntoarcerea veno-arterială a sângelui prin PCA cu solicitarea ventriculului drept.

Din cauza formei severe a coarctației de aortă, semnele clinice au debutat încă din prima zi de naştere prin semne de insuficiență cardiacă congestivă brutal instalată şi tradusă clinic prin tahipnee, cianoză, extremități inferioare reci cu puls absent la nivelul arterelor femurale şi pedioase.

Fluxul sistemic al extremităţii inferioare a corpului fiind ductal dependent, s-a administrat prostaglandina E1 $0,1 \mathrm{mcg} / \mathrm{kg}$ pentru menținerea permeabilității canalului arterial, urmărindu-se cu atenţie apariţia efectelor secundare.

Corecția chirurgicală prin rezecția CoAo cu anostomoză extinsă termino-terminală a fost trata- mentul de elecție în acest caz datorită gradietului trancoarctație maxim $>20 \mathrm{mmHg}$, prezenței simptomatologiei trenante şi consecințelor hemodinamice (insuficiență cardiacă severă). Corecția CoAo în perioada precoce permite menținerea elasticității vasculare şi prevenirea dezvoltării hipertensiunii reziduale.

Însă, în pofida rezultatelor precoce favorabile postoperatorii, în multe clinici s-au raportat frecvent restenozarea la nivelul zonei de coarctație (20-86\%) (6-8), îndeosebi la pacienții cu vârstă de până la un an; dar utilizarea firelor resorbabile în locul celor de mătase a determinat o scădere semnificativă a restenozării.

Numeroase studii relatează că aproximativ 68\% dintre pacienții care au suferit intervenție chirurgicală corectoare a coarctației de aortă în primul an de viață vor prezenta în evoluție hipertensiune arterială. Mecanismul fiziopatologic nu este pe deplin cunoscut, dar se parte că modificarea postoperatorie a arhitecturii arcului aortic şi afectarea sensibilității mecanoreceptorilor sunt factori favorabili în dezvoltarea hipertensiunii arteriale (10).

Aşadar, urmărirea periodică a pacientului printr-o anamneză amănunțită, un examen clinic complet cu palparea pulsului la nivelul arterelor femurale şi pedioase, măsurarea valorilor tensionale şi evaluarea ecocardiografică permit identificarea posibilelor complicații.

\section{CONCLUZII}

Coarctația de aortă severă cu circulație sistemică ducto-dependentă prezintă un debut neonatal sugestiv, necesitând un diagnostic cât mai precoce. Inițierea perfuziilor cu prostaglandină $\mathrm{E} 1$, pentru a menține permeabilitatea canalului arterial, evitarea suprasolicitării cardiace, a supraîncărcării circulației pulmonare şi tratamentul chirurgical sunt etapele esențiale în managementul acestor cazuri. 